\title{
健康小兒血漿蛋白質の電氣泳動法的政究
} Electrophoretical Study on Bloodplasma of healthy Children

Yuji Hashimoto, Chizuko Nagayoshi, Masakazu Ogata

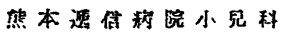 \\ 橋 元 莂二・永好千鶴子

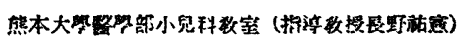 \\ 緒方昌一
}

\section{Electrophoretical Study on Bloodplasma of Healthy Children}

\author{
Yuji Hashimoto, Chizuko Nagayoshi \\ (Dept. of Pediatrics, Kumamoto Communication Hospital) \\ Masakazu Ogato \\ (Dept. of Pediatrics, Kumamoto Univ., Chief ; Prof. S. Nagano)
}

Electrophoretic analyses on blocd plasma of children are so rare in our country that we studied the plasma prctein analysis on 22 healthy childrer, 14 cases in 6 years (grcup A) and 8 yases in 2-4 years old (group B), with Tiselius' apparatus using Schlieren-diagcnal method (Type HT-B Hitachi mace).

Poled plasma were dialyzed for 16-2J hours, before electrophoresis, against 1/20 M phosphate buffer.

Experimental conditions were as follcws; electric voltage 90-140 V., electric current 9-10 mA., time cf electrophoresis $40-80$ minutes, temperature at $16^{\circ} \mathrm{C}$., Diagonal-Slit angle $25^{\circ}$.

The results are shown in the next Table.

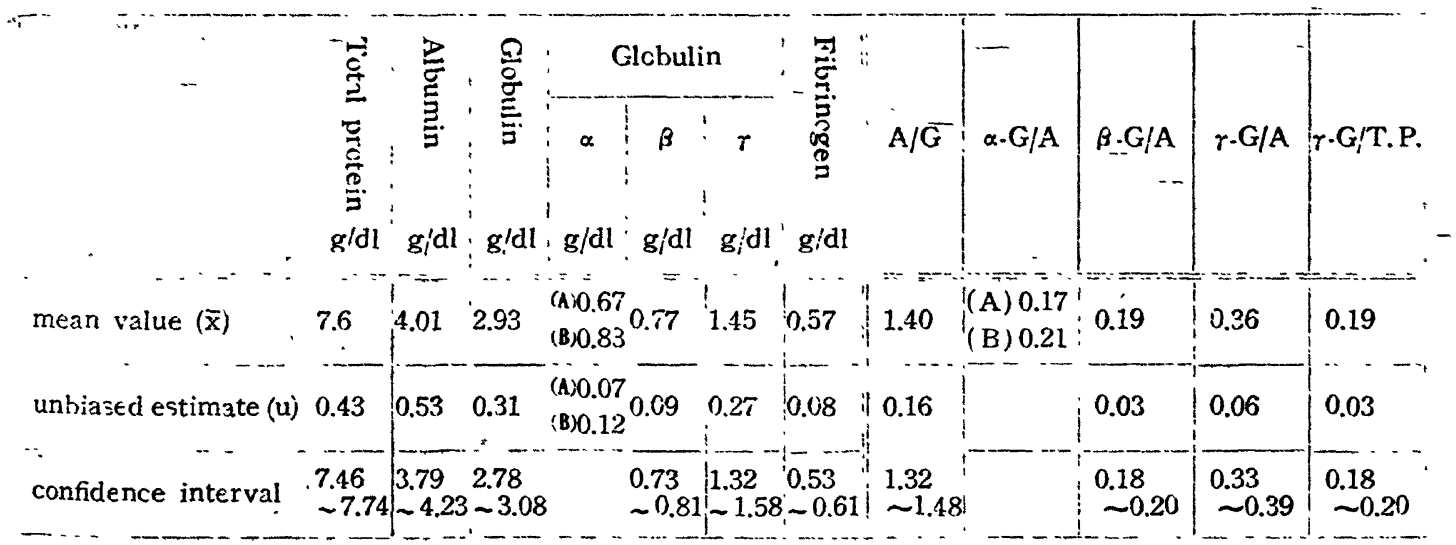

In comnarison with those values of the adult which were reported by many authors,

1) tctal protein shcwed no remarkable difference,

2) alubumin some decrease, ard

3) globulin no remarkable difference.

3) globulin no remarkable difference.

4) a-Globulin was not able to be compared with that of the adult, because there was significant difference between group A ard B. This may well be due to difference of time of electrophoresis.

5) B-Globulin shcwed no remarkable differnce,

6) $r$-globulin some increase, ard

7) fibrinogen no remarkable difference.

\section{1. 緒言}

近時䉓氣泳動泆に上る血装蛋白の䂺究は極めて活墢に

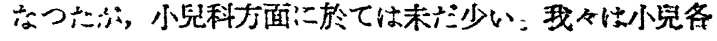

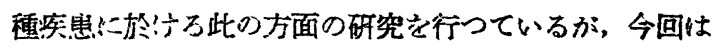

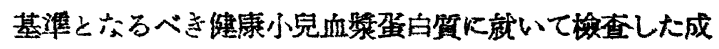


樍を報告する。

\section{2. 實 驗 方 法}

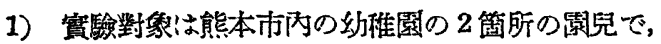
健康と認さべき者夫々 14 名，8名㖕22名。㨲血は午湔 11 時前後行行い，二重修酸盖を以て血愁を分離した。

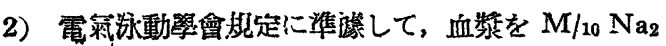
$\mathrm{HPO}_{1} 9$ 容, $\mathrm{M} / 10 . \mathrm{KH}_{2} \mathrm{PO}_{1} 1$ 容混合燐酸䌊衙拨で稀

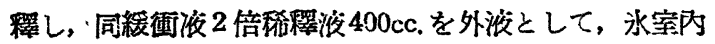
注於て16時間乃至20時間唀析した。

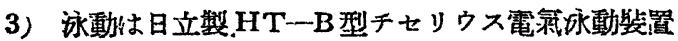
を用いた。

4) 操作条作として，水䅦溫度 $16^{\circ} \mathrm{C}$ 以下，電捱 90 万 至 $140 \mathrm{~V}$, 電流 9 乃至 $10 \mathrm{~mA}$, 泳慟時間40分乃至 80 分, Diagonal-Slit 倾斜角25。

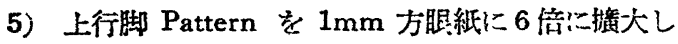

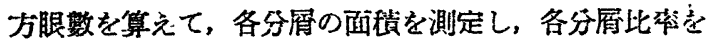
算出した。

6）蛋白濃度は日立蛋白喰记よつた。

7）以上の方法仗よつて,總蛋白量, Albumin, Globalin, $\alpha$-Glob.. $\beta$-Glob., Fibrinogen, $A / G, \alpha-G_{;}^{\prime} A$, $\beta-G / A, \gamma$-G/A, $\gamma$-G/T.P. を睢出した。

\section{3. 䨘 驗 成 績}

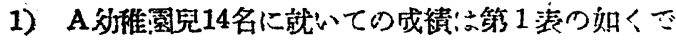

ある。

2）B妙椎固兒 8 名に就いての成績は第 2 表の如くで ある。

3）而して第1表中の症例No. 7，第2表中の No. 5, No. 6 は $\gamma$-Glob. 值が他に比べて高すぎるので Smirn-

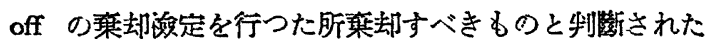
ので，之等の例では, $\gamma$-Glob., A/G, $r-G / A, r-G / T . P$. 値は爾後の算定から除外した。又第 2 表中 No. 7 及び 8 は血洯分離に際して, 暧度の溶血, 凝固を起し, 且その Fibrinogen 值は菓却谕定により萧却すべきものと認め

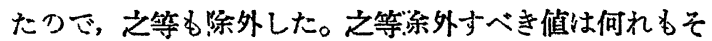

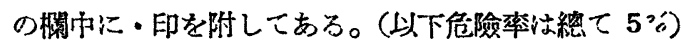

4）斯くして第 1 表，第 2 表の實測値加各項目每儿 その本均 $(\bar{x})$ 站分散不祏推定值 $(\boldsymbol{u})$ を計算寸ると第 3 表の脲になる。但し Glob., $r$-Glob., Fib., A/G,

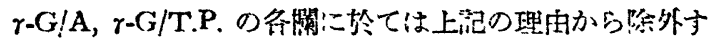

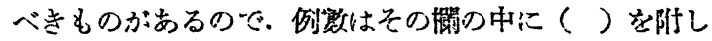

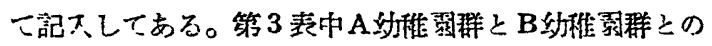

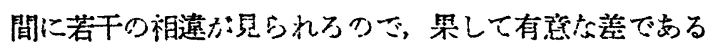

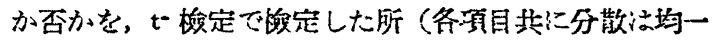

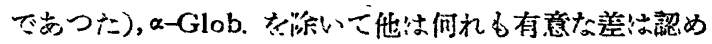

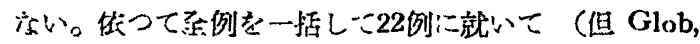
$\gamma$-Glob., A/G, $\gamma$-G/A, $\gamma$-G/A, $\gamma$-G/T.P. は19列, Fib.

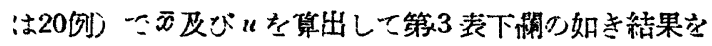
得た。

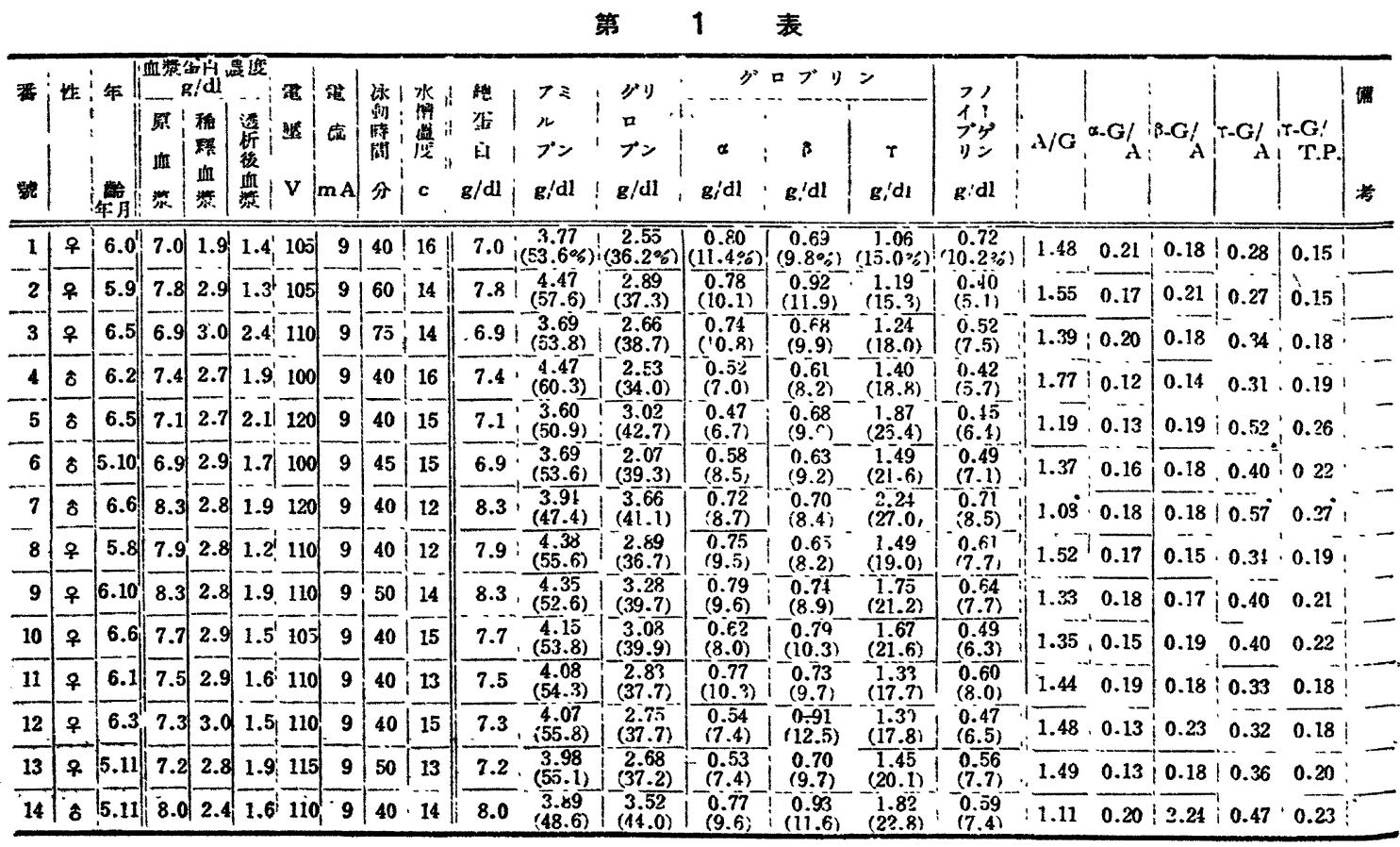


第 2 表

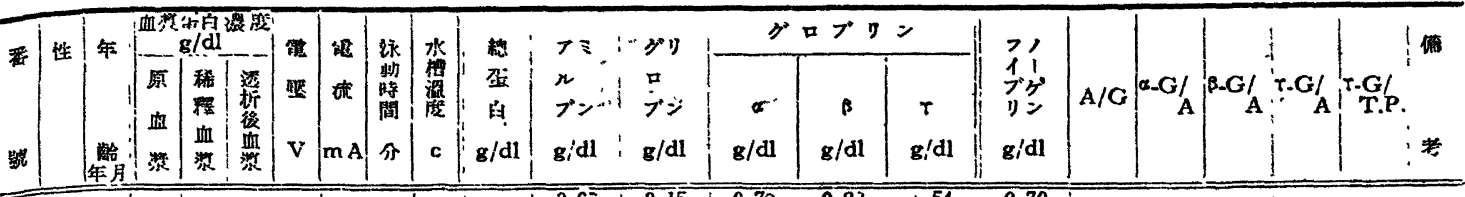

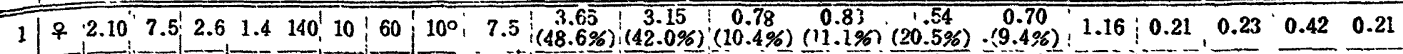

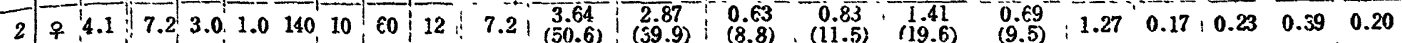

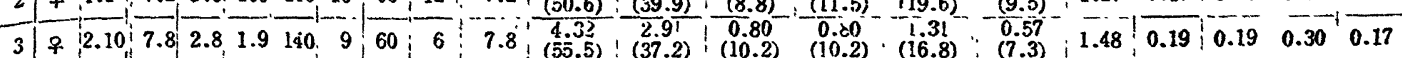

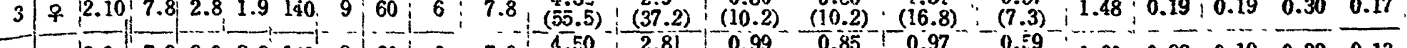

\begin{tabular}{ll|l|lllll|l|l|l|l|l|l|l|l|l|l|l|l}
2 & 2.81 & 0.99 & 0.85 & 0.97 & 0.59 & 1.60 & 0.22 & 0.19 & 0.22 & 0.13
\end{tabular}

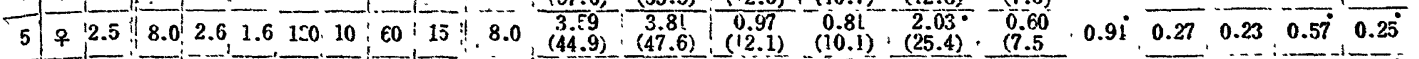

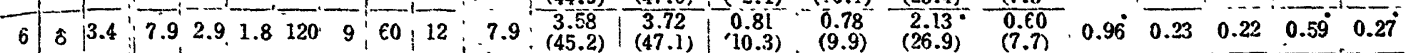

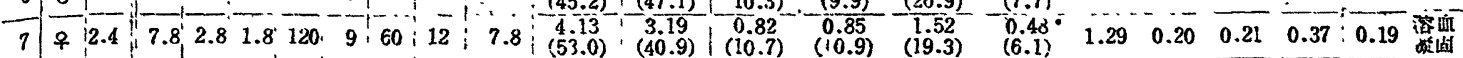

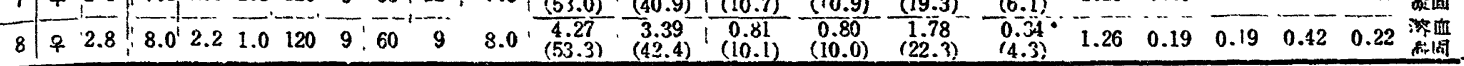

第 3 表

\begin{tabular}{|c|c|c|c|c|c|c|c|c|c|c|c|c|c|c|}
\hline \multirow{2}{*}{ 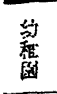 } & \multirow{2}{*}{ 咧 } & \multirow{2}{*}{$\begin{array}{l}x \\
L_{k}^{x} \\
u\end{array}$} & \multirow{2}{*}{$\begin{array}{l}\text { T.P. } \\
\mathrm{g}_{\text {idl }}\end{array}$} & \multirow{2}{*}{$\begin{array}{l}\text { Alb- } \\
\text { gidl }\end{array}$} & \multirow{2}{*}{$\begin{array}{l}\text { Glob. } \\
\text { g/dl }\end{array}$} & \multicolumn{3}{|c|}{ Glob. $g_{\prime}^{\prime}$ dl } & \multirow{2}{*}{$\begin{array}{l}\text { Fib. } \\
\text { g/dl }\end{array}$} & \multirow{2}{*}{$\mathrm{A} / \mathrm{G}$} & \multirow{2}{*}{$\alpha G / A$} & \multirow{2}{*}{$\beta-G / A$} & \multirow{2}{*}{ r-G:A } & \multirow{2}{*}{ T-GiT.P. } \\
\hline & & & & & & $\alpha$ - & $\beta$ & $r$ & & & & & & \\
\hline \multirow{2}{*}{ A } & \multirow{2}{*}{14} & $x$ & 7.5. & 4.01 & $\begin{array}{r}(13) \\
2.87 \\
\end{array}$ & 0.67 & 0.74 & $\begin{array}{r}-(13) \\
1.47 \\
\end{array}$ & 0.55 & $\begin{array}{l}(13) \\
1.42\end{array}$ & 0.17 & 0.19 & $\begin{array}{l}(13) \\
0.37\end{array}$ & $\begin{array}{l}(13) \\
0.20\end{array}$ \\
\hline & & $u$ & 0.44 & 0.59 & $\begin{array}{l}(1.3) \\
0.34\end{array}$ & 0.07 & 0.11 & $\begin{array}{l}(1.3) \\
0.27\end{array}$ & 0.10 & $\begin{array}{l}(13) \\
0.17\end{array}$ & 0.03 & 0.03 & $\begin{array}{l}(13) \\
0.05\end{array}$ & $\begin{array}{l}(13) \\
0.03\end{array}$ \\
\hline & \multirow{2}{*}{8} & $\bar{x}$ & 7.8 & 3.96 & $\begin{array}{l}(6) \\
3.05\end{array}$ & 0.83 & 0.82 & $\begin{array}{r}\text { (6) } \\
1.42\end{array}$ & $\begin{array}{l}(6) \\
0.63 \\
\end{array}$ & $\begin{array}{r}(6) \\
1.34\end{array}$ & 0.21 & 0.21 & 0.35 & $\begin{array}{l}(6) \\
0.19\end{array}$ \\
\hline & & $u$ & 0.28 & 0.38 & 0.23 & 0.12 & c. 04 & 0.27 & $\begin{array}{c}(6) \\
0.02\end{array}$ & 0.15 & 0.03 & 0.02 & $\begin{array}{l}(6) \\
0.08\end{array}$ & $\begin{array}{l}(6) \\
0.03\end{array}$ \\
\hline \multirow{2}{*}{$\begin{array}{l}A \\
+ \\
\text { B }\end{array}$} & \multirow{2}{*}{22} & $\dot{x}$ & 7.6 & 4.01 & $\begin{array}{l}(19) \\
2.93\end{array}$ & & 0.77 & $\begin{array}{l}(19) \\
1.45\end{array}$ & $\begin{array}{l}(20) \\
0.57\end{array}$ & $\begin{array}{l}(19) \\
1.40\end{array}$ & - & 0.19 & $\begin{array}{r}(19) \\
.0 .36\end{array}$ & $\begin{array}{l}(19) \\
0.19 \\
\end{array}$ \\
\hline & & $u$ & 0.43 & 0.50 & $\begin{array}{l}(19) \\
0.31\end{array}$ & & 0.09 & $\begin{array}{r}-(19) \\
0.27\end{array}$ & $\begin{array}{l}(20) \\
0.08\end{array}$ & $\begin{array}{l}(19) \\
0.16\end{array}$ & & 0.03 & $\begin{array}{l}(19) \\
0.0 \bar{b}\end{array}$ & $\begin{array}{l}(19) \\
0.03\end{array}$ \\
\hline
\end{tabular}

第 4 表

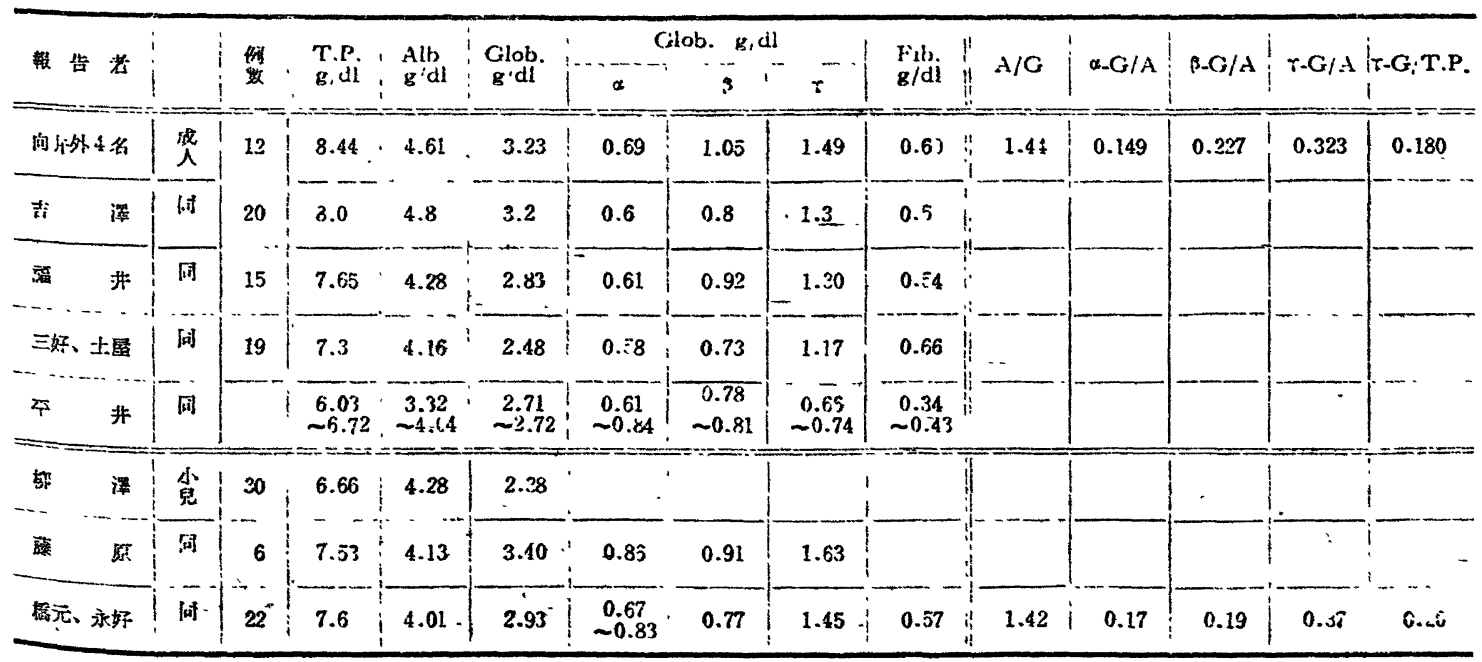




\section{4. 總括站考按}

小兒科領域に於ける血獎蛋白の㸴究は未だ少い。成人 伦於ては售氏によつて報告されているが，多少の相違が 見受けられる。今諸氏の派告を素示寸れば第4 素の漾: なる。

1）總蛋白量は最も正確なのはキールダール泆である

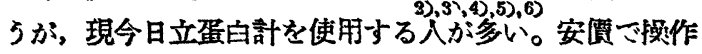
・が簡單であり，資料が微量で确むからであるう。我々も この理由から日立蛋白計を使用したが，预䚛筫驗とし て，成人血繁14訽就いて，プルフリッ七清浸屆折蛋白

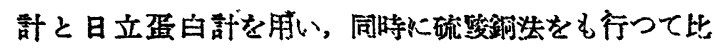

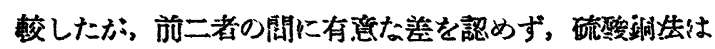
その值稍低く有意な差を談めた。㚹澤は健䐂小兒30例: 就いて Gomall, Bordanill \& Daird 法により測定し, 本均 $6.66 \mathrm{~g} / \mathrm{dl}$ を得, 更に Malloy の $6.5 \sim 8.0 \mathrm{~g} / \mathrm{dl}$, Harison の5.6 8.5 g/dl (平均7.0 g/dl), 落沪の6.5 8.2

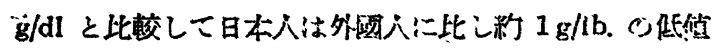

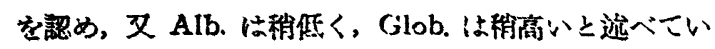

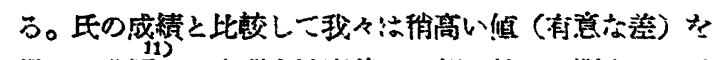

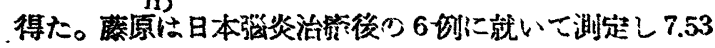

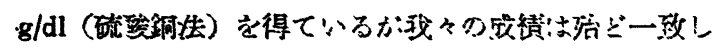
ている。

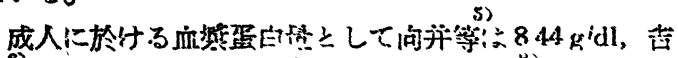

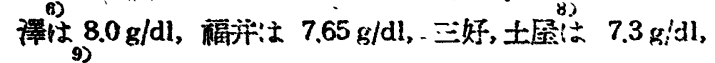

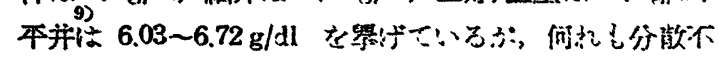
偏推定値が示ミれていないたー比較

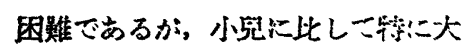
小は論じられない上らに然われる。

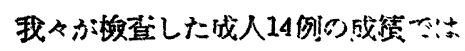
$\infty 7.97 \mathrm{~g} / \mathrm{dl}, u 0,54^{\circ}$ - 皮人之小元

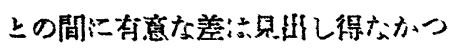

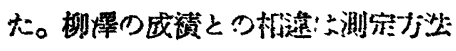
の美䓗づくものと考总ら。

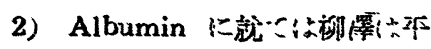
均 $4.28 \mathrm{~g} / \mathrm{dl}$ 之运へ，我々つ成紸上 有意な美を認めた。成原泣平均 4.13

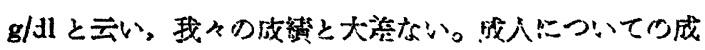

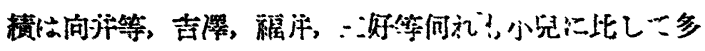

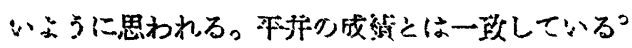

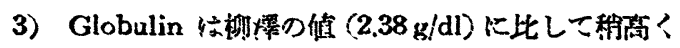
有意な差を証めた。藤原の成綕は可成り高い值を示して

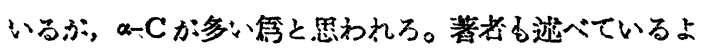

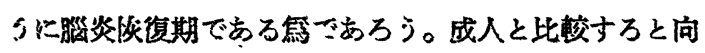

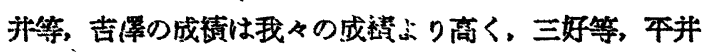

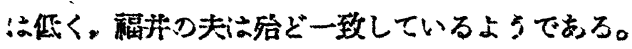

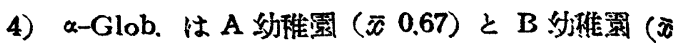
0.83）との間に有意な差を認める。これ分何に由来うる

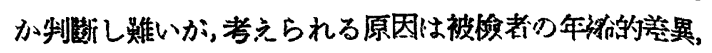
血等泳動時間の是短及び水槽溫度の高低である。この中

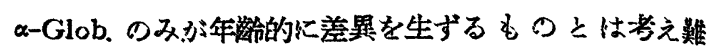

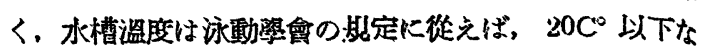

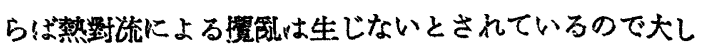
た意跦はないように芳元られる。泳動時間に就ては、小

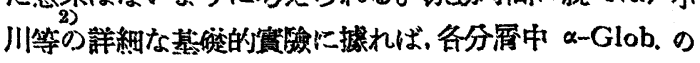

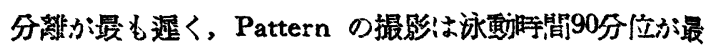
良で，r-Glob. の分離を必漹とする時は 120 分以上泳動

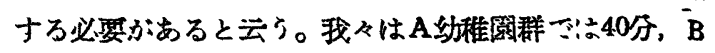

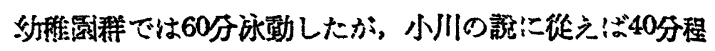
度では恐らく不无分なのであるう。この時問的相遠が原

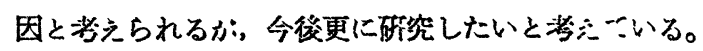

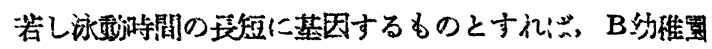

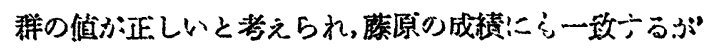

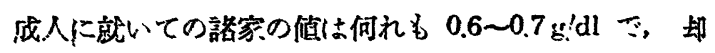

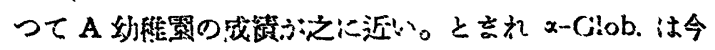
後更に砄究を罢する。

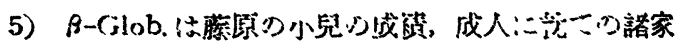

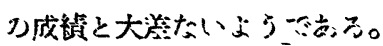

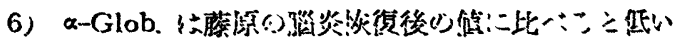

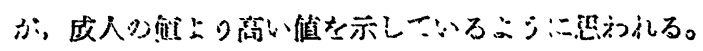

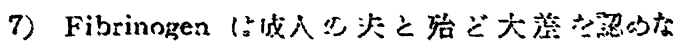
$\therefore$ 冫

第 5 表

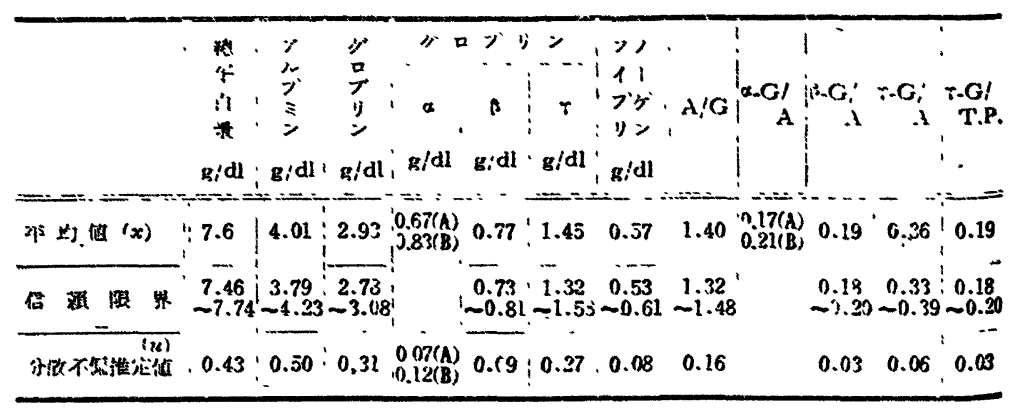

\section{5. 結論}

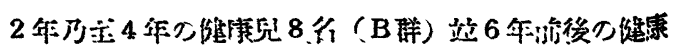

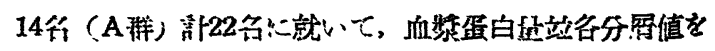
測定して头责の如き成樍を得た。

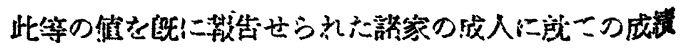
と比較するに,

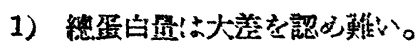

(32頁人筑人) 


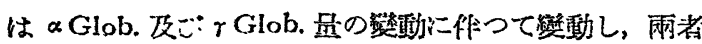

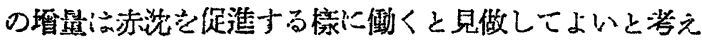

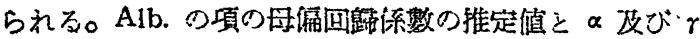
Glob.の項つそれ々の差が有望であるこんから Alb.は 赤沈に對して $\alpha$ Glob. 欧で $r$ Glob. と異る態度を取る因

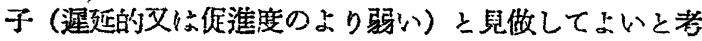
えられる。從來の監析法に上る蛋白贺行履と電氣泳動分 屑とは同一なものではないがここの絬果は盟析法による Alb. は逥延的，Glob. は促淮的，Fibrinogen は促進的 に作用すうとえ゙う多くの報告の結果と颣似したものであ る。

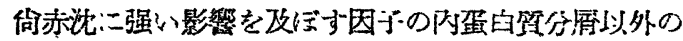

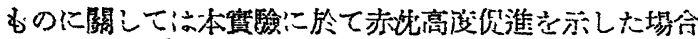

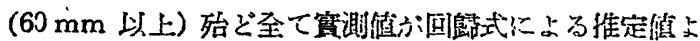

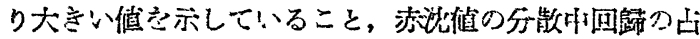

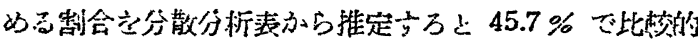

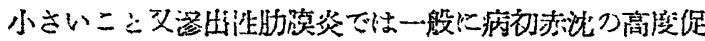

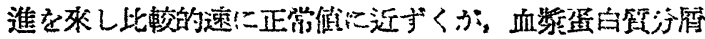
恃之さり掘れて正常值に近ずく傾间を見せること等を教

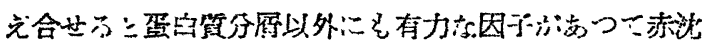
に影響さ欧ばしていると思われる。

\section{總括}

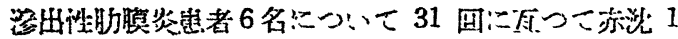

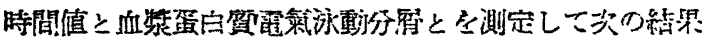
を得た。

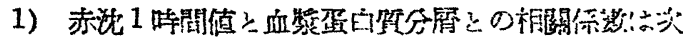
の゙通り゙ぜある。

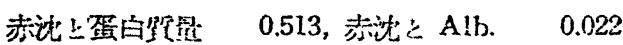

赤沈： $\alpha$-Glob. 0.453, 赫乞 $\beta$-Glob. 0.513

赫上 Fibrinogen 0.313, 赫记云 $\gamma$-Cilob. 0.442

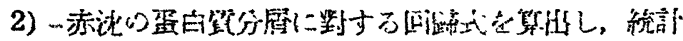

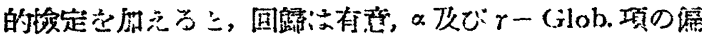

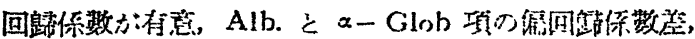

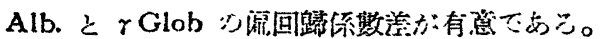

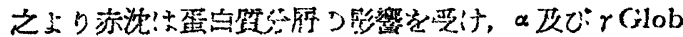

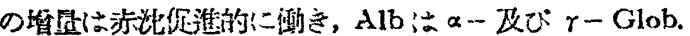

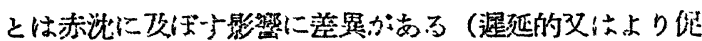

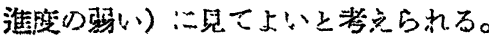

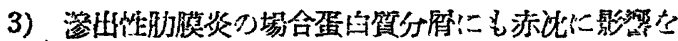
质仿与有力志因子が存在士るらしい。

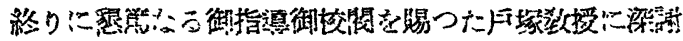
す。

\section{主 要 交 献}

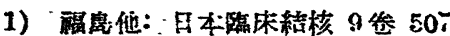

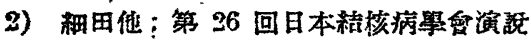

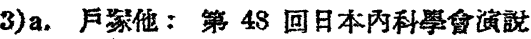

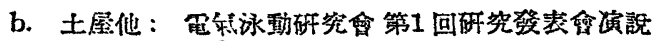

4) 加藤：日本臨作綰核 9 参 547

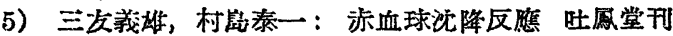

6）統計数倠表 河出囊房刊

7）获口繁一：初等数理統計學 度交館刊

（46頁より維く）

2）Albumin 泣成人值よりも稍低値を示す。

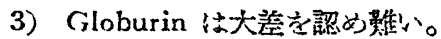

4） $\alpha$-Globulin 注A稀とB群との間に有意な美があ

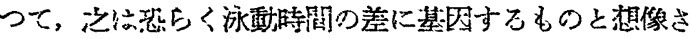

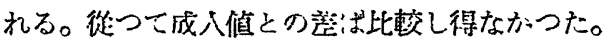

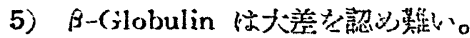

6） $\gamma$-Globulin は成人:比して梢高储示与。

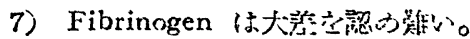

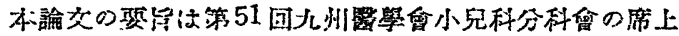

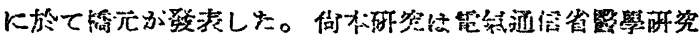

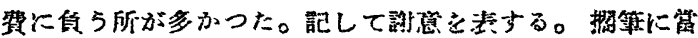

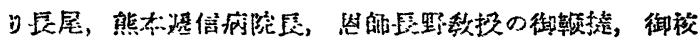

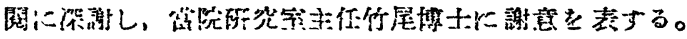

\section{女献}

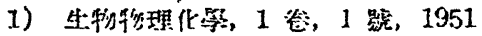

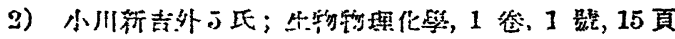
1951.

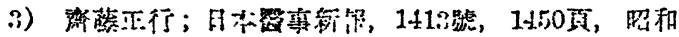
26 和

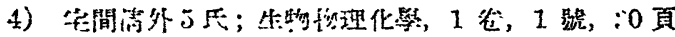
1951.

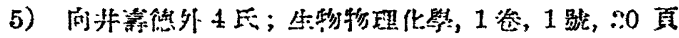
1951 ,

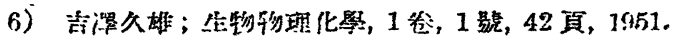

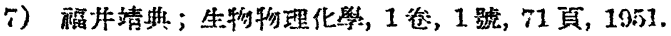

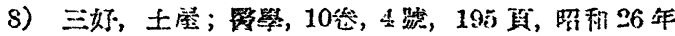

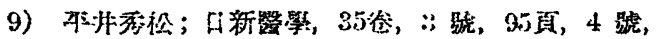
146页, 昭和29?

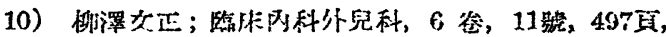
昭社26种:

11）藤原弘；兒科維誌，54参，1號，分頁，昭和25年 